\author{
Anna Zimnowodzka \\ Wyższa Szkoła Języków Obcych \\ im. Samuela Bogumiła Lindego w Poznaniu \\ azimnowodzka@go2.pl
}

\title{
Święta Eulalia z Barcelony - początki kultu pierwszej patronki miasta
}

\begin{abstract}
Abstrakt
Święta Eulalia, męczennica z początku IV wieku, była pierwszą - i do XIII wieku jedyną - patronką Barcelony. Choć do jej szczątków, spoczywających dziś w poświęconej jej od IX wieku katedrze, do dziś przybywają pielgrzymi z różnych stron świata, jest to postać pod wieloma względami problematyczna. Źródła pisane są późne, a archeologiczne niejednoznaczne. Niniejszy artykuł, uwzględniający ponowną weryfikację tekstów źródłowych i wyników dotychczasowych badań archeologicznych, stanowi próbę uporządkowania informacji i włączenia się w trwającą od lat dyskusję badaczy na temat ,prawdziwych” początków kultu Świętej Eulalii w Barcelonie.
\end{abstract}

Słowa kluczowe: kult, Barcelona, Frodoin, Eulalia, Santa María del Mar

\begin{abstract}
Saint Eulalia from Barcelona - Beginnings of the Cult of the First City Patroness

Saint Eulalia, who was martyred at the beginning of the $4^{\text {th }}$ century, was the first and until the $13^{\text {th }}$ century the only one - patron saint of Barcelona. Although pilgrims from around the world still keep venerating her relics, which already in the $9^{\text {th }}$ century were reposed in the city's cathedral, her figure is problematic in
\end{abstract}


many respects. Written sources are late and archaeological records are equivocal. This paper, reconsidering all kinds of sources, attempts to organise the information they contain and join the scholarly discussion on the "true" beginnings of the Saint Eulalia cult in Barcelona.

Keywords: cult, Barcelona, Frodoin, Eulalia, Santa María del Mar

Do czasu objawień Najświętszej Maryi Panny Łaskawej (Mare de Déu de la Mercè) Świętemu Piotrowi Nolasco w 1218 roku, co zaowocowało rozkwitem jej kultu w Barcelonie (Peredo Meza, 1997: 27n, 62; Garí, 2010: 475n), pierwszą i do XIII wieku jedyną patronką miasta była Święta Eulalia, która, jak głosi tradycja, oddała życie za wiarę w czasie prześladowań za panowania cesarza Dioklecjana ${ }^{1}$. Historia jej męczeństwa przekazywana była z pokolenia na pokolenie, ulegając $\mathrm{z}$ czasem różnym modyfikacjom. $\mathrm{Z}$ tego powodu, a także $\mathrm{z}$ innych względów, ustalenie ,prawdziwych” początków kultu świętej w rodzimym mieście okazało się zadaniem niezwykle złożonym. Po pierwsze, kłopotów nastręcza ustalenie historyczności samej świętej. Problematyczne wciąż pozostaje ustalenie lokalizacji jej pochówku, a także określenie początków kultu Eulalii w jej macierzystym mieście.

Zgodnie z wielowiekową tradycją miała ona pochodzić z okolic Barcelony, gdzie zginęła śmiercią męczeńską i gdzie została pochowana. Część badaczy uważa jednak, że przekonanie to nie znajduje wystarczającego potwierdzenia w materiale źródłowym. Najwcześniejszy

${ }^{1}$ Innym związanym $\mathrm{z}$ Barceloną męczennikiem $\mathrm{z}$ tego samego okresu jest Święty Kukufat. Pierwszą wzmiankę o nim znajdujemy w Peristefanon Prudencjusza, Pe IV, 33n. (CCL 126: 287 lub Aureliusz Prudencjusz Klemens (2006), Wieńce męczeńskie (Peristephanon), M. Starowieyski (wstęp i oprac.), tłum. M. Brożek, Wydawnictwo WAM, Kraków: 201). Historię jego męczeństwa znamy z późniejszej VIII-wiecznej Passio Cucufatis, z której dowiadujemy się, że torturowany w Barcelonie święty został wyprowadzony poza mury miejskie, w miejsce oddalone o 8 mil od miasta, zwane Castrum Octavianum (obecnie utożsamiane z Sant Cugat de Valles), i tam został ścięty (Passio Cucufatis, 12, za: Fábrega Grau, 1953, Pasionario Hispánico, t. 2, s. 314, dalej cyt. jako: Pasionario Hispánico). To tam właśnie, w miejscu męczeńskiej śmierci Kukufata, a nie w Barcelonie, pojawił się i rozkwitł jego kult. 
tekst dotyczący Eulalii z Barcelony, Passio Eulaliae Barcinonensis (z końca VI lub początku VII wieku) ${ }^{2}$, tak bardzo przypomina wcześniejszą, IV-wieczną passio Świętej Eulalii z Meridy pt. Passio Eulaliae Emeritensis (Pasionario Hispánico, t. 2: 68-78), że część badaczy skłania się ku teorii, że dziewczyna, która jest czczona od wieków w Barcelonie, to w istocie umęczona w Meridzie Eulalia, której sława dotarła do Barcino i w pewnym momencie historia jej męczeństwa dała impuls do zainicjowania kultu nowej lokalnej świętej o tym samym imieniu (Fábrega Grau, 1958: 11-18; Villalón, 1976: 449-458; Banks, 1981: 194n) ${ }^{3}$. Choć kwestia ta wciąż dzieli badaczy, rozpoczęty

${ }^{2}$ Passio Eulaliae Barcinonensis w: Fábrega Grau, 1953, t II: 233-237 oraz Riesco Chueca, 1995: 104-113. Zgodnie z zapisem bollandystów w Bibliotheca Hagiografica Latina (Bruselas, 1898-99) oraz w Suplemencie do BHL (Bruselas, 1911) istnieją trzy wersje Passio opisujące śmierć męczeńską Eulalii: pierwsza BHL, 2.693, z końca VI lub z VII wieku, która znalazła się w Pasionario Hispánico i jedyna, która weszła na stałe do liturgii mozarabskiej, druga: BHL, 2.694, napisana w 1106 roku przez gramatyka (grammaticus) Remallo z Barcelony (zachowana w XIV-wiecznym kodeksie 107 z katedry w Barcelonie) i ostatnia: BHL, 2.696 (i kilka wariantów tej wersji), prawdopodobnie z VIII wieku, napisana prawdopodobnie poza granicami Hiszpanii, zupełnie nieznana na Półwyspie, zob. A. Fábrega Grau (1958), Santa Eulalia de Barcelona. Revísión de un problema histórico, Iglesia Nacional Española, Roma, s. 53n.

${ }^{3}$ Passio Eulaliae Emeritensis jest niemal dwa razy dłuższa od Passio Eulaliae Barcinonensis, głównie ze względu na rozbudowane dialogi między namiestnikiem Kalpurnianem a Eulalią oraz obszerne opisy tortur, którym poddawano męczennicę. Jednak kluczowe wydarzenia w jednej i drugiej passio są zbliżone. Obie Eulalie mieszkały w pewnej odległości od Meridy (Emerita) i Barcelony (Barcino) (Passio Eulaliae Emeritensis, 4; Passio Eulaliae Barcinonensis, 2). Po przybyciu zarządcy do miasta (w Meridzie był to Kalpurnian, w Barcino Dacjan) każda z nich udała się na forum (Passio Eulaliae Emeritensis, 7; Passio Eulaliae Barcinonensis, 5). Tam wyznały wiarę i poddane zostały torturom, m.in. biczowaniu, rozciąganiu na łożu sprawiedliwości, przypalaniu pochodniami (w passio Eulalii z Meridy opisów tortur jest więcej, m.in. wylewania gorącej oliwy lub ołowiu na nagie ciało Eulalii czy okładania go gorącą gliną). Obie zostały ukrzyżowane i spalone żywcem (na stosie lub pochodniami). $Z$ ust jednej i drugiej po śmierci wyfrunęła gołębica (Passio Eulaliae Emeritensis, 17; Passio Eulaliae Barcinonensis, 8). Świadkiem śmierci męczeńskiej w jednym 
z końcem IV wieku kult „Eulalii z Barcelony” niewątpliwie w VII wieku stał się faktem. Historię jej męczeństwa poznajemy dzięki pochodzącej z tego okresu Passio Eulaliae Barcinonensis. Dowiadujemy się z niej, że była to dobrze sytuowana trzynastoletnia dziewczyna, która mieszkała w pewnej odległości od Barcelony [longius a ciuitate (Barcinona)] (Passio Eulaliae Barcinonensis, 2) ${ }^{4}$. Kiedy prześladowania chrześcijan dotarły na Półwysep Iberyjski, przybył do Barcelony namiestnik Dacjan. Podczas pobytu w mieście nakazał mieszkańcom składać ofiary bożkom pogańskim. Wszyscy, którzy odmawiali, mieli zostać skazani na okrutne tortury (PEB, 3). W reakcji na to zarządzenie wczesnym rankiem Eulalia udała się do bram miasta i skierowała na forum (Que quum ingrederetur portam ciuitatis, audiuit preconiam uocem sonantem et perrexit ad forum) (PEB, 5), aby stanąć przed trybunałem. Tam wyznała wiarę w Boga i odmówiła posłuszeństwa Dacjanowi. Została za to skazana na tortury: najpierw na karę chłosty (PEB, 6), później rozciągano ją na łożu tortur, następnie powieszono za ręce i rozszarpywano hakami (PEB, 7), a na koniec przypalano jej ciało ogniem. Kiedy wyzionęła ducha, z jej ust uleciała ku niebu gołębica. To cudowne wydarzenie zadziwiło wszystkich zebranych na forum (PEB, 8). Rozwścieczony Dacjan nakazał zawiesić jej ciało na krzyżu, tak aby mogły je rozdziobać ptaki. Jednakże w tym samym momencie spadł śnieg, przykrywając umęczone ciało Eulalii. Przez kolejne dni przybywali na miejsce męczeństwa liczni pielgrzymi, którzy pragnęli dostąpić łaski cudu w obecności jej doczesnych szczątków. Po trzech dniach, pod osłoną nocy, zostały one zebrane, owinięte w nasączone wonnościami płótno i pochowane w obecności licznych mieszkańców Barcino (Post diem autem tertium uiri religiosi nocte abstulerunt corpus eius, non sentientes custodes, quod cum

i drugim przypadku był Święty Feliks (w Emericie także Donat) (Passio Eulaliae Emeritensis, 19; Passio Eulaliae Barcinonensis, 9). W każdej passio pojawia się również motyw śniegu, który przykrył umęczone członki męczennic (Passio Eulaliae Emeritensis, 18; Passio Eulaliae Barcinonensis, 9). Ich szczątki były zbierane w sekrecie i pochowane w nieokreślonym przez autorów miejscu (Passio Eulaliae Emeritensis, 19; Passio Eulaliae Barcinonensis, 9).

${ }^{4}$ Pasionario Hispánico, t. 2: 233, dalej PEB. 
linteis et a romatibus inuolberunt) (PEB, 9). Mimo że autor, opisując uroczystości pogrzebowe, wspomina o psalmach, które podczas nich śpiewano, zupełnie pomija kwestię lokalizacji miejsca pochówku Eulalii (Et ad vocem psallentium multi e populo conuenerunt et mox cum letitia sepelierunt eam) (PEB, 9).

Wskazówki o umiejscowieniu jej grobu nie znajdujemy także w datowanym na VII wiek hymnie na cześć świętej Fulget hic honor sepulcri (PL 86: 1099n). W tym przypisywanym biskupowi Kwiricusowi (Quiricius) $)^{5}$ utworze odnajdujemy jedynie wzmiankę o ufundowaniu przez niego klasztoru, wzniesionego przy grobie Eulalii, o czym sam autor tak wspomina:

Conquirat et Quiricius,

Qui tui locum sepulchri

Regulis monasticis

Ad honorem consecravit (PL 86: 1100).

O pierwotnym miejscu spoczynku świętej dowiadujemy się dopiero $\mathrm{z}$ datowanego na koniec IX wieku tekstu Translatio beatae Eulaliae ${ }^{6}$, w którym autor opowiada o cudownym odnalezieniu relikwii Eulalii w basilica Sanctae Virginis (Translatio beatae Eulaliae, 3) oraz o ich uroczystym przeniesieniu do katedry. Wiadomo zatem, że szczątki

${ }^{5} \mathrm{Na}$ temat autorstwa hymnu zob. J. Pérez de Urbel (1926), Origen de los himnos mozárabes, BulHisp 28, 2: 135n. J. Pérez de Urbel uważa, że ten hymn napisany został przez biskupa Barcelony Kwiricusa. Zwraca uwagę, że w spisie biskupów Barcelony widnieje imię biskupa Kwiricusa (Quiricius) z drugiej połowy VII wieku, który korespondował z biskupem Julianem z Toledo. Analiza treści jedynego zachowanego listu wskazuje, że był to człowiek światły, posługujący się pięknym językiem, zatem z powodzeniem mógł być autorem hymnu. Kwiricus (Quiricius) brał również udział w synodzie w Toledo w 653 roku.

${ }^{6}$ Tekst Translatio beatae Eulaliae zachował się w trzech manuskryptach z Archiwum Kapituły Katedralnej w Barcelonie: manuskrypt 105 „Santorale” („Flores sanctorum”) z początku XIV wieku (s. 72r-73v), manuskrypt 104 „Sanctorale primum seu vetustius" $\mathrm{z}$ drugiej połowy XIV wieku lub z początku wieku XV (s. 197b-199c) oraz manuskrypt 108 „Santorale” (pars tretia), również z końca XIV lub początku XV wieku (s. 74r-77r) (Fábrega Grau, 1958: 109). Wydanie krytyczne tekstu zob. Fábrega Grau, 1958: 151-155. 
Eulalii spoczywały pierwotnie w bazylice Najświętszej Maryi Panny. W jej poszukiwaniu pomocny okazał się średniowieczny materiał źródłowy, na który składają się XI-wieczne rozporządzenia testamentowe i donacyjne na rzecz kościołów Barcelony. Zachowały się w nich m.in. informacje o dwóch poświęconych Najświętszej Maryi Pannie bazylikach (basilica Sanctae Virginis), identyfikowanych z zachowanymi do dziś kościołami Santa María del Mar i Santa María del Pi (Banks, 1981: 335) (ilustracja 1).

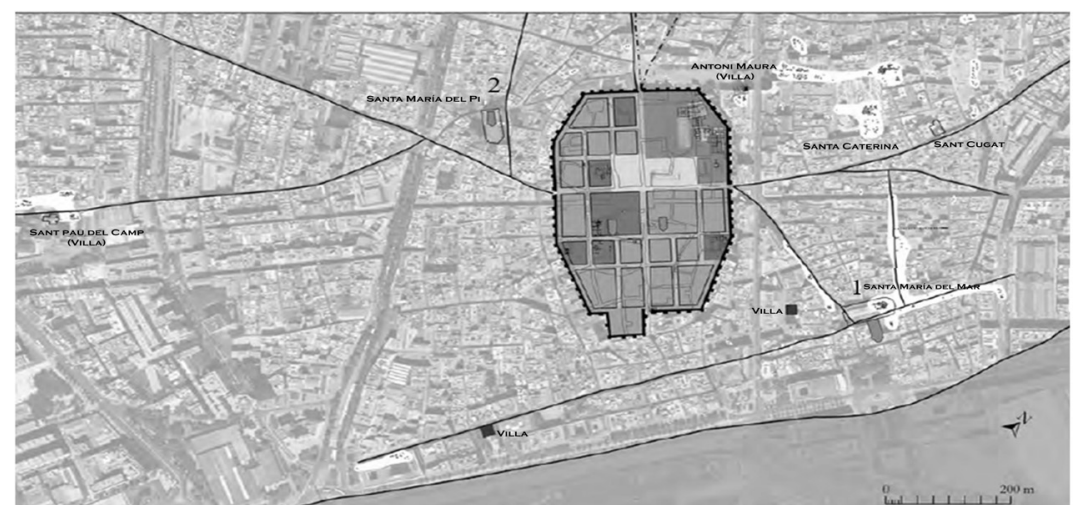

Ilustracja 1. Hipotetyczny plan Barcino oraz kościoły Santa María del Mar (1) oraz Santa María del Pi (2) extra muros miasta (Beltrán de Heredia Bercero, 2011: 107, zmodyfikowany przez A. Zimnowodzka)

Ponieważ początki obu bazylik sięgają czasów wczesnochrześcijańskich, wydaje się wysoce prawdopodobne, że jedna z nich była pierwotnym miejscem pochówku Eulalii. Dokładniejszych informacji na temat lokalizacji pierwszej z nich dostarczają XI-wieczne dokumenty zachowane w Archiwum Kapituły Katedralnej w Barcelonie ${ }^{7}$. W treści jednego z testamentów z 1001 roku bliscy niejakiego Bonhoma (Riculfus, Bellaron,

${ }^{7}$ Dokumenty zebrane i opublikowane przez: Baucells i Reig et al. (2006), Diplomatari de l'Arxiu Capitular de la Catedral de Barcelona. Segle XI, t. 1, Fundació Noguera: Barcelona. 
Audesindus oraz Imola), realizując wolę zmarłego, ofiarowują bazylice Sancta Maria Maris littore qui est ante portam civitatis Barchinona winnicę w pobliżu Badalony (in terminio de Bitulona) (Baucells i Reig et al., 2006: 290). Podobną informację znajdujemy w pochodzącym z 1004 roku dokumencie donacyjnym niejakiego Arnulfa i jego żony Ermesindy, którzy deklarują, że są darczyńcami domum Sancta Maria, cuius baselica sita est ante muros civitatis Barchinona, in ipsa littora maris (Baucells i Reig et al., 2006: 323).

Z obu dokumentów wynika, że kościół Sancta Maria znajdował się poza murami miasta, przed bramą miejską (ante portam, ante muros), a także w pobliżu morza (Sancta Maria Maris Littore, in [...] littora maris). Wskazówki te skłoniły badaczy do identyfikowania go z bazyliką, która została wybudowana w miejscu, na którym w 1329 roku rozpoczęto budowę gotyckiego kościoła Santa María del Mar.

O tym, że wspomniana bazylika mogła być w istocie pierwotnym miejscem spoczynku Eulalii, mogą świadczyć również wyniki badań archeologicznych prowadzonych między 1940 a 1967 rokiem (Ribas Beltrán, 1967: 195-228; Sales-Carbonell, 2011: 62; Travesset i Queraltó, 2005: 73-112; Beltrán de Heredia Bercero, 2011). Szczególne znaczenie miały prace z 1966 roku, przeprowadzone pod ołtarzem głównym oraz kryptą. Odkryto tam 102 miejsca pochówku datowane na okres między IV a VI wiekiem, wskazujące na obecność rozległej chrześcijańskiej nekropolii, której obecność potwierdzono również na terenie przyległych ulic. Zdaniem badaczy na uwagę zasługuje tu widoczne w okolicach ołtarza głównego zjawisko tumulatio ad santos, czyli wyjątkowe stłoczenie miejsc pochówku wokół jednego, uważanego za szczególny, należący do męczennika. Znamienna wydaje się także obecność pod posadzką obecnego kościoła pozostałości murów przedromańskiej budowli, co mogłoby oznaczać, że wcześniej wznosiła się w tym miejscu bazylika (ilustracja 2). Wśród elementów ruchomych wyposażenia kościoła znajdował się wykonany w warsztacie rzymskim sarkofag strygilowy z marmuru prokonezyjskiego (Banks, 1981: 224). Choć nie znaleziono żadnych dowodów na powiązanie sarkofagu ze Świętą Eulalią, to ze względu na jego wysokiej klasy warsztat, wyróżniający go spośród pozostałych znalezisk 
archeologicznych, został on w pierwszej chwili uznany przez badaczy za domniemany sarkofag męczennicy. Mimo że obecnie środowisko naukowe neguje jego związek z Eulalią, sarkofag ten, przechowywany dziś w Muzeum Archeologicznym miasta, wciąż utożsamiany jest przez miejscową ludność z tym, w którym miały spocząć szczątki Świętej Eulalii (Beltrán de Heredia Bercero, 2011: 113n; Ribas, 1967a: 17; Sales-Carbonell, 2011: 62).

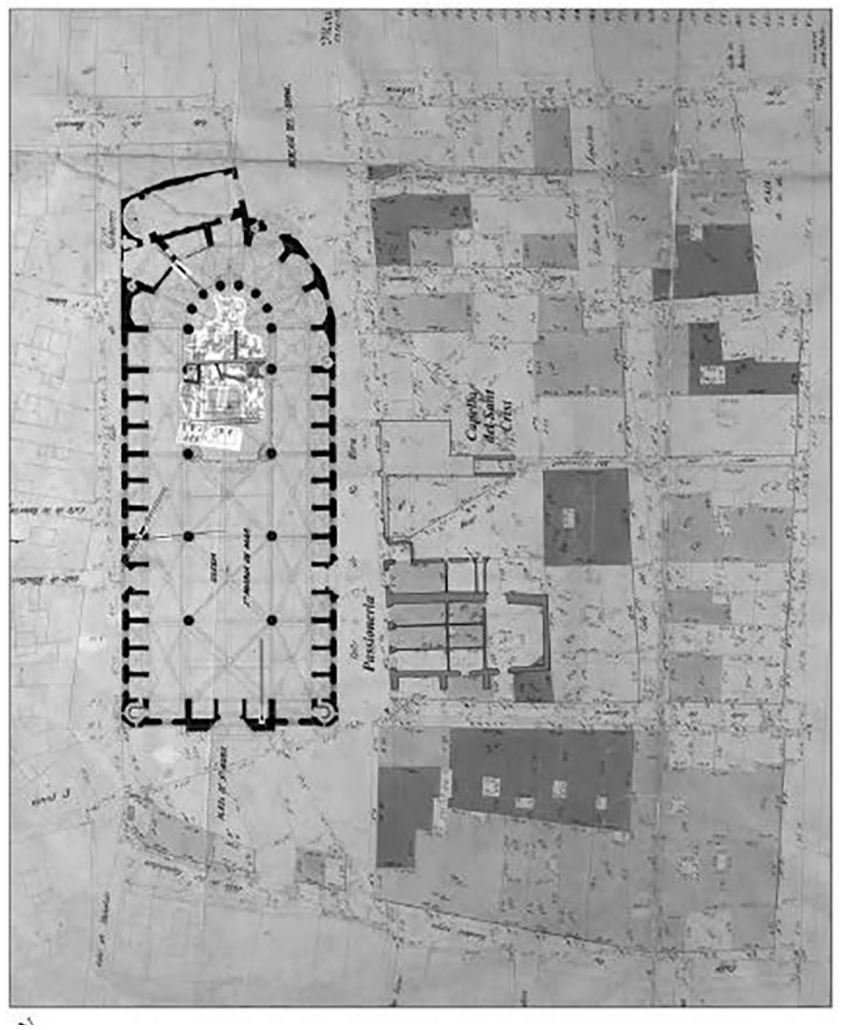

Ilustracja 2. Plan kościoła Santa María del Mar z zaznaczonym obszarem prac archeologicznych prowadzonych pod ołtarzem głównym w 1966 roku (Beltrán de Heredia Bercero, 2011: 123) 
W ostatnich latach pojawiła się nowa koncepcja o lokalizacji grobu Świętej Eulalii w drugim ze wspomnianych wyżej kościołów poświęconych Maryi - Santa María del $\mathrm{Pi}^{8}$. Jako argumenty przemawiające za tą teorią jej zwolennicy wskazują na wyjątkowe zagęszczenie toponimów związanych ze Świętą Eulalią w tej okolicy oraz fakt, że kościół został wzniesiony tuż przed bramą miejską. Zwracają również uwagę na znaleziony w nim wtórnie użyty w funkcji ołtarza piedestał rzymski z widocznym otworem na relikwie (loculus) (Conde Moragues, 2013: 54-62). Wszystkie wymienione argumenty, choć warte rozważenia, nie znalazły dotychczas potwierdzenia w skromnym materiale archeologicznym (znamienny wydaje się w tym miejscu zwłaszcza brak miejsc pochówku) i wymagają dalszych, dogłębnych badań (Rodà de Llanza, 2016: 263n).

Pytanie, gdzie znajdowało się pierwotne miejsce pochówku świętej, wciąż pozostaje bez jednoznacznej odpowiedzi. Brakuje również jakichkolwiek informacji o tym, jak rozwijał się kult Eulalii po uroczystościach pogrzebowych $(P E B, 9)$. Aż do VII wieku na temat kultu Eulalii w mieście nie zachowały się żadne informacje, dlatego fakt, że z tego okresu zachowały się dwa teksty źródłowe (Passio oraz hymn Fulget hic honor sepulchri), pozwala uznać VII wiek za czas szczególnego rozkwitu kultu Eulalii w mieście. Pamięć o męczennicy zanika ponownie po 712 roku, wraz z inwazją muzułmańską na Półwysep Iberyjski ${ }^{9}$. Jej kult odrodził się w IX wieku, po odbiciu miasta przez

${ }^{8}$ Informacji o kościele dostarczają przede wszystkim zachowane zapisy testamentowe, m.in.: Testament Joana z 1036 roku, Testament Marii z 1038, a zwłaszcza datowany na 1062 Testament biskupa Guisalberta, który przepisał na rzecz kościoła liczne dobra i posiadłości, zob. J. M. Martí i Bonet, G. Pallàs, J. Alarcón (2017), Novum speculum titulorum ecclesiae barchinonensis. Arquebisbat de Barcelona. Resum de documents, t. 1, Barcelona, s. 383n.

${ }^{9}$ Barcelona została zajęta przez Arabów w 712 roku. I choć w tym trudnym dla miasta okresie teksty źródłowe milczą na temat Świętej Eulalii, wiadomo jednak, że jej sława jeszcze w VIII wieku przekroczyła granice Półwyspu. Jej wspomnienie pojawia się w anglosaskim Martyrologium Bedy Czcigodnego, aczkolwiek autor Martyrologium korzystał z passio, która powstała zdaniem badaczy poza granicami Półwyspu (zob. przypis 2) (Fábrega Grau, 1958: 116). 
wojska frankijskie, kiedy to „w roku 801, [...] Ludwik, wówczas król Akwitanii, z polecenia swego ojca [Karola Wielkiego] zajął Barcelonę" (cyt. za: Collins, 1996: 330; O’Callaghan, 1975: 106) ${ }^{10}$. Podjęto wówczas próbę utworzenia marchii granicznej na południe od Pirenejów, pełniącej funkcję strefy buforowej między państwem Franków a terenami zajętymi przez Omajjadów. Barcelona została stolicą jednego z hrabstw Marchii, w której utworzono jego administrację (Collins, 1996: 330; González Ruiz, 2012: 18-25). Na stanowiskach zarządców obsadzono hrabiów fankijskich sprzyjających monarchii Karolingów. Podobnie rzecz się miała z hierarchami kościelnymi (Garí, 2010: 477).

W 861 roku Karol Łysy desygnował na biskupa Barcelony wpływowego i lojalnego duchownego Frodoina (Vergés Trias, Vinyoles Vidal, 2000: 20n), któremu oficjalnie powierzył ambitną misję podniesienia rangi katedry w mieście i zastąpienia liturgii wizygockiej rytem rzymskim (Vergés Trias, Vinyoles Vidal, 2000: 21), a przy okazji ocieplenia wizerunku i umocnienia pozycji cesarza. Około 877 roku cesarz wysłał list skierowany do mieszkańców Barcelony (omnibus Barchinonensibus peculiaribus nostris), by podziękować im za wszelkie dobro czynione na rzecz miasta, a jednocześnie poprosić o renowację katedry. W swojej korespondencji poinformował także, że na ten cel ofiarował biskupowi Frodoinowi 10 funtów srebra (dirigo ad Frodoynum, episcopum, libras $X$ de argento ad suam ecclesiam

${ }^{10}$ Wyprawa Ludwika Pobożnego była poprzedzona w 778 roku ekspedycją za Pireneje samego Karola Wielkiego. W 777 roku cesarz spotkał się w Patebornie ze sprzymierzonymi przeciwko Omajjadom z Kordoby wysłannikami możnowładców arabskich sprawujących kontrolę nad Saragossą (Husayn de Zaragoza), Barceloną (Sulayman ben al-Arabí) oraz Huescą (Abu Taur), którzy zwrócili się do króla Franków z prośbą o pomoc w związku z zagrożeniem ze strony Kordoby. Okazało się jednak, że kiedy Karol Wielki przybył do Saragossy, nie otworzono mu bram miasta. Po bezskutecznym miesięcznym oblężeniu cesarz zdecydował się na odwrót. Wycofując wojska przez wąwóz Roncevaux, jego tylna straż została zaskoczona i rozgromiona przez Basków (Collins, 1996: 296n, O’Callaghan, 1975: 102). Szerzej na temat podboju Barcelony przez Franków również: Salrach, J. M. (1997), El procés de formació national de Catalunya (segles VIII-IX), t. 1, Edicions 62, Barcelona. 
reparare) (ACB, Ms. Privilegiorum regum, num. 1, f. 9) ${ }^{11}$. Ten znaczący gest zbiegł się w czasie z innym niezwykłym wydarzeniem, którego głównym bohaterem był sam biskup Frodoin. Było to cudowne odnalezienie relikwii Świętej Eulalii w kościele Sancta Maria, o którym informacje zachowały się w dwóch źródłach pisanych. Pierwszy z nich to datowany na koniec IX wieku, wspomniany wyżej tekst Translatio beatae Eulaliae ${ }^{12}$. Jego autor opisuje wydarzenia z 877 roku, które miały miejsce podczas pobytu w mieście czcigodnego arcybiskupa Sigeboda z Narbony (venerabilis Sigebodus archiepiscopus) (Translatio beatae Eulaliae, 3). Przybył on wówczas do sąsiedniej Barcinony z misją pozyskania relikwii Świętej Eulalii, dla której zamierzał erygować kościół w Narbonie. Podejmujący go biskup Frodoin przez trzy dni bezskutecznie usiłował odnaleźć grób męczennicy, aby spełnić życzenie gościa. Po intensywnych poszukiwaniach zrezygnowany Sigebod opuścił Barcinonę (vir venerabilis Sigebodus archiepiscopus remeavit ad propria) (Translatio beatae Eulaliae, 3). Frodoin nie dał jednak za wygraną i w intencji odnalezienia relikwii Eulalii rozpoczął intensywne trzydniowe modlitwy i post, do których przyłączyli się wszyscy mieszkańcy miasta (ieiunaverunt omnes viri atque mulleres, pussilli et magni, alii in domibus suis), a także znaczna część duchownych (turba magna clencorum) (Translatio beatae Eulaliae, 4). Na trzeci dzień podczas mszy w bazylice Sanctae Virginis zauważył po prawej stronie ołtarza szczelinę, w którą zatknął swój pastorał. Nakazał w tym miejscu kopać, a w trakcie wykonywanej pracy zaczęła

${ }^{11}$ Oryginał listu przechowywany jest w Archiwum Kapituły Katedralnej w Barcelonie (ACB). W całości jako pierwszy opublikował go w 1603 roku F. Diago: Historia de los victoriosissimos antiguos Condes de Barcelona. Diuidida en tres libros, Sebastian de Cormellas al Call: Barcelona, s. 62n. Badania nad tekstem prowadził, a następnie opublikował wraz z komentarzem krytycznym profesor J. Calmette w 1902 roku: „Une lettre close originale de Charles le Chauve", Mélanges de l'école française de Rome, 22, Rome, s. 135n. Na uwagę zasługuje również ostatnia publikacja Alturo i Perucho, J., Alaix, T. (red.) (2017), Chartae Latinae Antiquiores. Part CXII, Spain I, Urs Graf Verlag, Dietikon-Zürich, $14 \mathrm{n}$.

12 Zob. przypis 6. 
unosić się wspaniała woń (exivit ex eo odor suavissimus ac si sepulcrum illud ómnibus unguentis preciosis fuisset plenum) (Translatio beatae Eulaliae, 4). Kiedy natrafiono na sarkofag ze szczątkami Świętej Eulalii, Frodoin zdecydował o ich uroczystym przeniesieniu do katedry Świętego Krzyża ad sedem [...] quae dedicata est in honore Sanctae Crucis (Translatio beatae Eulaliae, 5) ${ }^{13}$.

Upamiętnieniem translacji relikwii świętej jest datowana na IX wiek inskrypcja na marmurowej płycie (o wymiarach $0,34 \times 0,80 \mathrm{~m}$ ), na którą natrafił przypadkiem w 1774 roku ojciec Jaume Caresmar w krypcie obecnej katedry (ilustracja 3) ${ }^{14}$.

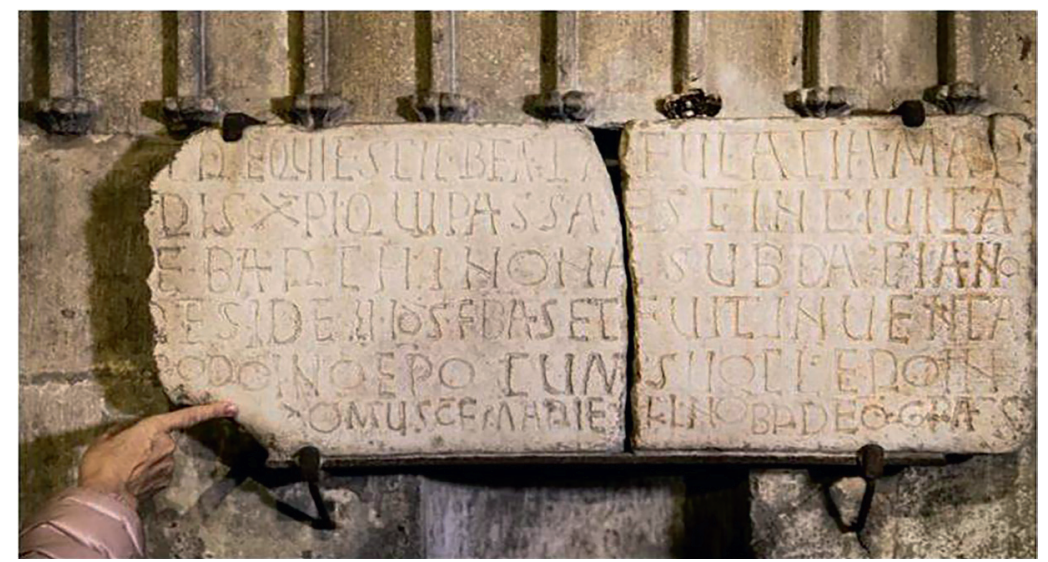

Ilustracja 3. Płyta z inskrypcją datowana na IX wiek (https://www.lavanguardia.com/local/barcelona/20190501/461969611175/silla-mas-antigua-barcelona-catedral.html)

13 Fábrega Grau uważa, że pierwsza część tekstu (1-6) pochodzi z IX wieku, pozostała część prawdopodobnie mogła zostać dopisana przy okazji kolejnej translacji szczątków z romańskiej katedry do gotyckiej krypty w nowej katedrze (Fábrega Grau, 1958, 109n).

14 Jaume Caresmar powiedział ojcu Risco o swoim znalezisku, który informację o nim zamieścił w pośmiertnym XXIX tomie dzieła Enrique Flóreza España Sagrada, zob. Flórez, t. 29: 314n. 
Zgodnie z jego opisem była ona umieszczona za urną na prochy, którą uznał za pierwotny sarkofag Świętej Eulalii1 ${ }^{15}$. Jej treść jest następująca:

[Hi]c requiescit beata Eulalia mar

[ty]ris Chr(ist)i, qui passa est in civita

[t]e Barchinona sub Daciano

[p]reside II Id(us) f(e)b(ruari)as et fuit inventa

[a Fr]odoino ep(iscop)o cum suo clero in

domu(m) s(an)c(t)e Marie X K(a)l(endas) No(vem)br(es). Deo gra(tia)s.

(Hübner, 1900: núm. 519)

Trudno nie oprzeć się wrażeniu, że wszystkie wydarzenia i ich okoliczności mające miejsce po wyzwoleniu Barcelony przez Franków, czyli wysłanie ambitnego i lojalnego biskupa Frodoina poza Pireneje, szczodre gesty cesarza pod adresem społeczności lokalnej, wizyta biskupa Sigeboda z Narbony w celu pozyskania relikwii Świętej Eulalii, a także ich cudowne odnalezienie, miały przynieść przede wszystkim polityczne korzyści dla dynastii Karolingów i ugruntować pozycję wiernej cesarzowi hierarchii kościelnej.

Nie ma wątpliwości, że cudowne odnalezienie relikwii Eulalii i ich uroczyste przeniesienie do katedry podniosło znacząco jej rangę, gdyż od tej pory poświęcona była również świętej męczennicy. Jej kult rozprzestrzenił się poza granice miasta, a nawet Półwyspu (Fábrega Grau, 1958: 103n; Santiago Fernández, 2012: 155-156). Wspomnienia Świętej Eulalii pojawiły się jeszcze w IX wieku w martyrologiach z terenów Galii: w Anonimowym z Lyonu (z początku IX wieku) oraz Martyrologium Usuarda (z końca IX wieku) (Fábrega Grau, 1958: 116).

Na początku XI wieku zdecydowano o wyburzeniu popadającej w ruinę starej katedry i o wzniesieniu nowej budowli romańskiej, a wobec rozwijającego się kultu świętej męczennicy w XIV wieku położono kamień węgielny pod potężną gotycką budowlę, w której pod prezbiterium zaplanowano kryptę przeznaczoną na szczątki świętej

${ }^{15}$ Funkcję urny pełni fragment dekoracji architektonicznej, a jej pokrywa to wtórnie wykorzystana przegroda ołtarzowa. 
(ilustracja 4). Teksty źródłowe z tego okresu nie pozostawiają cienia wątpliwości, że kiedy dzieło zostało ukończone, dokonano powtórnego, bardzo uroczystego przeniesienia doczesnych szczątków Eulalii do krypty (Guasch Ferrer, 2002: 89), gdzie spoczęły w pięknym marmurowym sarkofagu, natomiast pierwotna urna i płyta z inskrypcją zostały zainstalowane tuż za nowym relikwiarzem na tylnej ścianie krypty i tam znajdują się do dziś (Guasch Ferrer, 2002: 82).

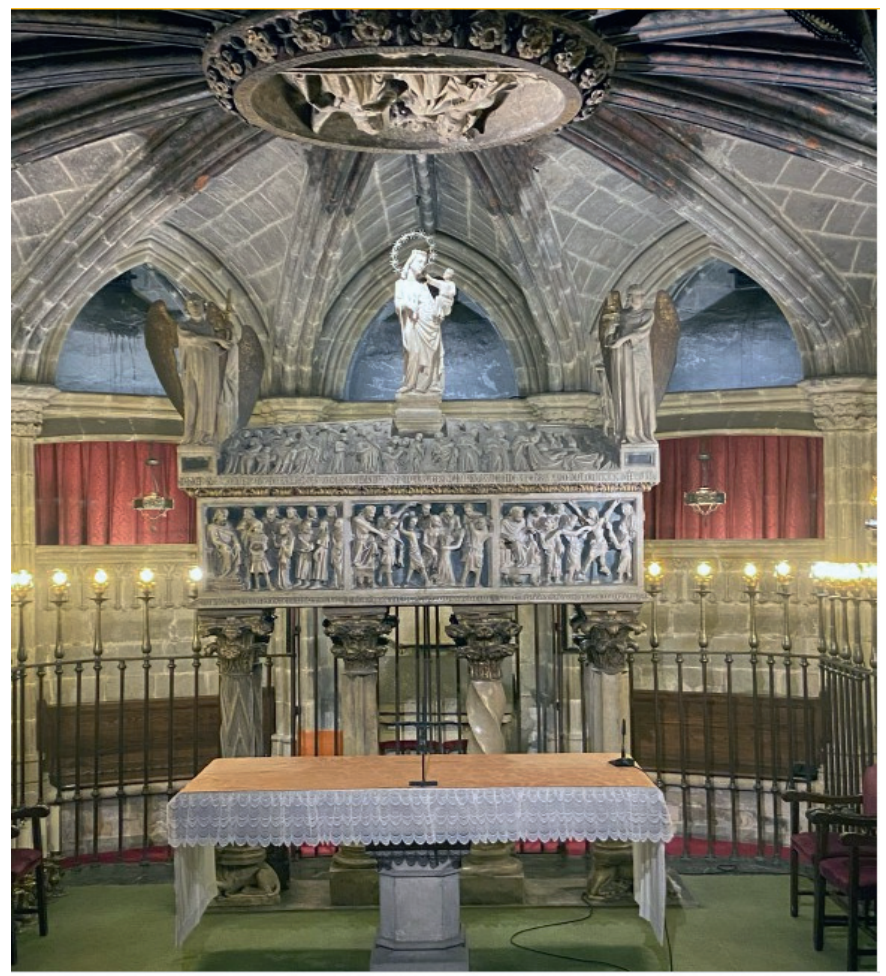

Ilustracja 4. Krypta z alabastrowym sarkofagiem, w którym aktualnie spoczywają domniemane szczątki Świętej Eulalii (https://www.poblesdecatalunya.cat/ element.php? $=2022$ ) 
Historia kultu Świętej Eulalii w Barcelonie, jakkolwiek niepozbawiona luk i miejscami domagająca się bardziej jednoznacznego potwierdzenia, wydaje się znakomitym przykładem ogromnej roli kultu miejscowych męczenników w historii religijnej, społecznej, a nawet politycznej późnoantycznych oraz średniowiecznych miast i zasługuje na dalsze dogłębne badania.

\section{Bibliografia}

ALTURO I PERUCHO, J. (2019), „Las epístolas en la Cataluña altomedieval. Un primer censo y algunas características" w: Sirantoine, H. (red.), $L a$ lettre diplomatique. Epistola 2, Casa Velázquez, Madrid.

ALTURO I PERUCHO, J., ALAIX, T. (red.) (2017), Chartae Latinae Antiquiores. Part CXII, Spain I, Urs Graf Verlag, Dietikon-Zürich.

BALIL, A. (1961), „Sobre el anfiteatro romano de Barcino”, Cuadernos de Arqueología e Historia de la Ciudad, 2, Barcelona, s. 148-152.

BANKS, P. J. (1981), The Topography of the City of Barcelona and Its Urban Context in Eastern Catalonia. From the Third to the Twelfth Centuries, University of Nottingham, Nottingham.

BAUCELLS I REIG, J. et al. (2006), Diplomatari de l'Arxiu Capitular de la Catedral de Barcelona. Segle XI, t. 1, Fundació Noguera, Barcelona.

BELTRÁN DE HEREDIA BERCERO, J. (2011), „Santa María del Mar. Un enclave cultual de la antigüedad tardía en el suburbium de Barcino", $Q u$ aderns d'Arqueologia i Història de la Ciutat de Barcelona, 7, Barcelona, s. 102-143.

CALMETTE, J. (1902), „Une lettre close originale de Charles le Chauve”, Mélanges de l'école française de Rome, 22, Rome, s. 135-139, https:// doi.org/10.3406/mefr.1902.6262.

COLLINS, R. (1996), Europa wczesnośredniowieczna 300-1000, Państwowy Instytut Wydawniczy, Warszawa.

CONDE MORAGUES, L. (2013), „Hipótesis sobre la posible identificación del anfiteatro de Barcino", Pyrenae, 2, Barcelona, s. 47-68.

FÁBREGA GRAU, A. (1958), Santa Eulalia de Barcelona. Revísión de un problema histórico, Iglesia Nacional Española, Roma. 
GARÍ, B. (2010), „La política de lo sagrado en la Barcelona medieval. De la Inventio Santae Eulaliae a las leyendas mercedarias", Imago Temporis. Medium Aevum, 4, Lleida, s. 475-490.

GONZÁlEZ RUIZ, D. (2012), Breve Historia de la Corona de Aragón, Ediciones Nowtilus, Barcelona.

GUASCH FERRER, M. (2002), „Renovación de los monumentos sepulcrales de Santos de la Corona de Aragón, en el siglo XIV", Boletín del Museo Arqueológico Nacional, 20, Madrid, s. 81-92.

HÜBNER, E. (1900), Inscriptiones Hispaniae Christianae. Supplementum, Berolini typis et impensis G. Reimeri, Berlin.

MARTI I BONET, J. M., PALLAS, G., ALARCON, J. (2017), Novum speculum titulorum ecclesiae barchinonensis. Arquebisbat de Barcelona. Resum de documents, t. 1, Bubok Publishing S.L., Barcelona.

O'CALlAGHAN, J. F. (1975), A History of Medieval Spain, Cornell University Press: Ithaca, London, https://doi.org/10.1080/03612759.1975.9 944920.

Passio Eulaliae Barcinonensis w: Fábrega Grau, A. (red.) (1953), Pasionario Hispánico (siglos VII-X), t. 1-2, Consejo Superior de Investigaciones Científicas. Instituto P. Enrique Flórez, Madrid-Barcelona, s. 233-237.

PEREDO MEZA, S. et al. (1997), La Orden de Santa María de la Merced (1218-1992). Sintesis histórica, Instituto Histórico de la Orden de la Merced, Roma.

RIBAS BELTRÁN, M. (1967), „Una necrópolis romana en la basílica de Santa María del Mar, de Barcelona”, Empúries. Revista de món clàssic $i$ antiguitat tardana, 29, Barcelona, s. 195-228.

RIESCO CHUECA, P. (red.) (1995), Pasionario Hispánico, Universidad de Sevilla, Sevilla.

RODÀ DE LLANZA, I. (2016), „Tarraco y Barcino en el Alto Imperio”, Revista de Historiografia, 25, Madrid, s. 245-272, https://doi.org/10.20318/ revhisto.2017.3585.

SALES-CARBONELL, J. (2011), „Santa María de las Arenas, Santa María del Mar y el anfiteatro romano de Barcelona", Revista d'Arqueologia de Ponent, 21, Lleida, s. 61-74.

SALRACH, J. M. (1997), El procés de formació national de Catalunya (segles VIII-IX), t. 1-2, Edicions 62, Barcelona. 
SANTIAGO FERNÁNDEZ, J. (2012), „Publicidad, escritura expuesta e iglesia en los condados catalanes (s. IX-XII)", Cuadernos de investigación histórica, 29, Madrid, s. 133-158.

Translatio beatae Eulaliae w: Fábrega Grau, A. (1958), Santa Eulalia de Barcelona. Revísión de un problema histórico, Iglesia Nacional Española, Roma, s. 151-155.

TRAVESSET I QUERALTÓ, M. (2005), „La realitat histórica de la mártir Eulalia a la Barcelona del segle IV. Resultats de les excavacions arquitectňniques de la necrópolis paleocristiana de Santa Maria del Mar”, Finestrelles, 13, Barcelona, s. 73-112.

VILLALÓN, J. (1976), „¿Dos Eulalias o una?”, Revista de estudios extremeños, 32, 3, Badajoz, s. 449-458.

VERGÉS TRIAS, M., VINYOLES VIDAL, T. M. (2000), „De la Seu de Frodoí a la Catedral romànica de Barcelona”, Boletín de la Real Academia de Buenas Letras de Barcelona, 47, Barcelona, s. 9-49. 